\title{
Tingkah Laku Makan Domba Lokal Muda yang Diberi Pakan dengan Level dan Sumber Protein Berbeda
}

\section{(Eating Behavior of Young Local Sheep Fed with Different Feed Levels and Sources of Protein)}

\author{
Luthfi MF, Purnomoadi A, Adiwinarti R \\ Fakultas Peternakan dan Pertanian, Universitas Diponegoro, Semarang \\ faridhluthfi@gmail.com
}

\begin{abstract}
Early fattening is an attempt to produce low-fat meat and cholesterol by accelerating the fattening phase. Early fattening should be supported by good quality feed that can be seen from the content of crude protein (CP) of feed. Crude protein can be derived from vegetable and animal protein sources. This study aimed to examine the effect of different levels and sources of protein on eating behavior of local lamb. Twenty heads of local lamb aged 3-4 months, body weight (BW) of $13.03 \pm 2.30 \mathrm{~kg}$ (CV 17.65\%). The study used a Completely Randomized Design (CRD) $2 \times 2$ factorial pattern, there were two protein levels $(13.36 \%$ and $15.20 \%$ ) and two protein sources (soybean meal and fish meal) with 5 replications. The diet was given adlibitum in pellet. Treatment was distinguished by 4 types of rations, T1 $(13.13 \%$ soybean meal), T2 (15.20\% soybean meal), T3 (13.58\% fish meal) and T4 (15.20\% fish meal). The parameters observed were eating time, rumination time and Dry Matter Intake (DMI). The results showed that eating time $(219.58 \mathrm{~min} / \mathrm{d})$, rumination time $(163.00 \mathrm{~min} / \mathrm{d})$ and DMI $(641.77 \mathrm{~g} / \mathrm{d})$ are not significantly different at levels and protein sources. It is concluded that giving different levels and sources of protein did not affect the eating behavior of local lamb.
\end{abstract}

Key words: Eating behavior, protein levels, protein sources, local lamb

\begin{abstract}
ABSTRAK
Penggemukkan dini merupakan upaya untuk menghasilkan daging rendah lemak dan kolesterol dengan mempercepat fase penggemukkan. Penggemukkan dini harus didukung dengan pakan yang berkualitas baik yang dapat ditinjau dari kandungan protein kasar (PK) pakan. Protein kasar dapat berasal dari sumber protein nabati dan hewani. Penelitian ini bertujuan untuk mengkaji pengaruh perbedaan level dan sumber protein terhadap tingkah laku makan domba lokal muda. Dua puluh ekor domba lokal jantan umur 3-4 bulan, Bobot Badan (BB) 13,03 $\pm 2,30$ kg (CV 17,65\%). Penelitian dilakukan dengan Rancangan Acak Lengkap (RAL) pola faktorial $2 \times 2$, terdapat dua level protein $(13,36 \%$ dan $15,20 \%)$ dan dua sumber protein (bungkil kedelai dan tepung ikan) dengan 5 ulangan. Pakan diberikan secara adlibitum dalam bentuk pellet. Perlakuan dibedakan dengan 4 jenis ransum yaitu T1 (bungkil kedelai 13,13\%), T2 (bungkil kedelai 15,20\%), T3 (tepung ikan 13,58\%) dan T4 (tepung ikan 15,20\%). Parameter yang diamati adalah waktu makan, waktu ruminasi dan konsumsi bahan kering (BK). Hasil penelitian menunjukkan bahwa waktu makan, ruminasi dan konsumsi BK pada level dan sumber protein tidak berbeda nyata dengan nilai rata-rata seluruh perlakuan yaitu 219,58 menit/hari, 163 menit/hari dan 641,77 g/hari. Disimpulkan bahwa pemberian level dan sumber protein yang berbeda tidak mempengaruhi tingkah laku makan domba lokal muda.
\end{abstract}

Kata kunci: Tingkah laku makan, level protein, sumber protein, domba lokal muda 


\section{PENDAHULUAN}

Penggemukkan dini pada domba merupakan upaya untuk menghasilkan daging rendah lemak dan kolesterol dengan mempercepat fase penggemukkan (Purnomoadi 2018). Penggemukkan dini pada umumnya dilakukan pada domba muda umur 3-4 bulan atau lepas sapih. Domba pada umur tersebut berada dalam fase pertumbuhan dipercepat (Ilham 2017), sehingga masa penggemukkan akan menjadi lebih singkat karena pertumbuhan tulang dan otot dapat maksimal. Salah satu jenis domba lokal yang berpotensi untuk dilakukan penggemukkan dini yaitu domba ekor tipis (DET) karena memiliki beberapa kelebihan antara lain mudah beradaptasi dengan lingkungan dan pakan baru serta memiliki produktivitas yang tinggi. Proses penggemukkan dini harus ditunjang dengan pemberian pakan yang berkualitas baik untuk mempercepat proses produksi.

Pakan yang berkualitas baik dapat dilihat dari kandungan nutriennya terutama protein kasar (PK). Pakan harus mengandung PK yang cukup untuk kebutuhan hidup pokok dan pertumbuhan. Domba muda membutuhkan PK yang lebih tinggi untuk mendukung proses pertumbuhan yang cepat. Hasil penelitian Prima et al. (2016) menggunakan DET jantan muda diperoleh hasil bahwa level PK yang terbaik adalah $14 \%$.

Protein pakan dapat berasal dari sumber protein nabati dan hewani. Salah satu sumber protein nabati dan hewani yang sering digunakan yaitu bungkil kedelai dan tepung ikan. Penggunaan bungkil kedelai sebagai sumber protein untuk pakan ruminansia dinilai masih kurang efisien karena tingkat degradasi protein bungkil kedelai di dalam rumen dapat mencapai 75\% (Uhi 2006). Tingkat degradasi protein yang tinggi dan tidak diimbangi dengan pembentukan protein mikroba yang tinggi pula membuat protein tidak dapat dimanfaatkan secara maksimal oleh ternak untuk produksi. Alternatif untuk menghindari kondisi tersebut yaitu mengganti penggunaan bungkil kedelai dengan tepung ikan karena memiliki tingkat degradasi protein di dalam rumen yang lebih rendah yaitu 40\% (Puastuti et al. 2008) serta merupakan sumber lemak dan mineral yang baik.

Level dan sumber protein yang berbeda dalam pakan diduga dapat mempengaruhi proses pencernaan didalam mulut dan rumen. Hal tersebut dapat dilihat dari tingkah laku makan ternak yang meliputi lama waktu ternak dalam mengkonsumsi dan meruminasi pakan. Penelitian Riyanto et al. (2015) dengan menggunakan kambing kacang, pemberian sumber protein yang berbeda menghasilkan waktu makan dan ruminasi yang berbeda. Disamping itu, Sabilla et al. (2015) dengan menggunakan kambing kacang muda, pemberian pakan dengan level PK berbeda menghasilkan waktu makan yang sama namun ruminasi yang berbeda. Proses makan ternak meliputi pengambilan pakan menggunakan mulut (prehensi), pengunyahan (mastikasi) dan proses salivasi yang kemudian penelanan (deglutisi) menuju rumen untuk difermentasi. Pakan yang difermentasi kemudian dikeluarkan (regurgitasi) dan dikunyah kembali (remastikasi) hingga menjadi partikel yang mampu lolos dari rongga rumen untuk proses pencernaan pasca rumen. Tingkah laku makan dapat memberikan informasi penting mengenai cara ternak mengkonsumsi pakan dan jenis pakan yang paling disukai sehingga program pemberian pakan menjadi lebih efisien (Goetsch et al. 2010).

Penelitian ini bertujuan untuk mengetahui pengaruh pemberian pakan dengan level dan sumber protein yang berbeda terhadap tingkah laku makan domba lokal muda. Manfaat dari penelitian ini yaitu dapat memberikan informasi tentang pengaruh pemberian pakan dengan level dan sumber yang berbeda terhadap tingkah laku makan domba lokal muda. 


\section{MATERI DAN METODE}

Penelitian mengenai tingkah laku makan dan ruminasi domba ekor tipis jantan muda yang diberi pakan dengan level dan sumber protein berbeda dilaksanakan pada bulan Agustus-Desember 2018 di Laboratorium Ternak Potong dan Perah, Fakultas Peternakan dan Pertanian, Universitas Diponegoro, Semarang.

\section{Materi penelitian}

Materi yang digunakan adalah 20 ekor domba lokal jantan umur 3-4 bulan dengan rataan bobot badan awal 13,03 $\pm 2,30 \mathrm{~kg}(\mathrm{CV}=17,65 \%)$. Pakan yang diberikan berupa pakan komplit berbentuk pellet dengan kandungan nutrien 13,36\% dan 15,20\% PK yang tersusun dari molases, gaplek, pucuk tebu, kulit singkong, bungkil kedelai, tepung ikan dan mineral.

Domba yang digunakan dalam penelitian ini ditempatkan pada kandang individu yang terbuat dari besi dan dilengkapi dengan tempat pakan dan minum. Timbangan digital dengan merk SF-400 kapasitas $10 \mathrm{~kg}$ untuk menimbang pakan dengan ketelitian $0,001 \mathrm{~kg}$. Mixer vertikal untuk mencampur bahan pakan dan peralatan sanitasi untuk membersihkan kandang. Peralatan pendukung pengambilan data tingkah laku makan adalah formulir isian manual tingkah laku makan dan stopwatch.

\section{Rancangan penelitian}

Rancangan penelitian yang digunakan adalah Rancangan Acak Lengkap (RAL) pola faktorial $2 \times 2$ dengan kombinasi 4 perlakuan dan 5 ulangan. Faktor pertama adalah level protein (A) dan faktor kedua sumber protein (B). Perlakuan yang digunakan adalah:

T1 $(\mathrm{A} 1 \mathrm{~B} 1)=$ Pakan komplit dengan PK 13,13\% dan menggunakan sumber protein bungkil kedelai

T2 $(\mathrm{A} 2 \mathrm{~B} 1)=$ Pakan komplit dengan PK 15,20\% dan menggunakan sumber protein bungkil kedelai

T3 $($ A1B2) $=$ Pakan komplit dengan PK 13,58\% dan menggunakan sumber protein tepung ikan

T4 $($ A2B2) $=$ Pakan komplit dengan PK 15,20\% dan menggunakan sumber protein tepung ikan

Tabel 1. Komposisi dan kandungan nutrien bahan pakan penelitian

\begin{tabular}{lcccc}
\hline \hline \multirow{2}{*}{ Uraian } & A1B1 & A2B1 & A1B2 & A2B2 \\
\cline { 2 - 5 } & \multicolumn{2}{c}{$\ldots \ldots \ldots \ldots \ldots \ldots \ldots \ldots \ldots \ldots \ldots \ldots \ldots \ldots \ldots \ldots \ldots \ldots \ldots \ldots \ldots \ldots \ldots \ldots \ldots \ldots$} \\
\hline Komposisi bahan pakan & & & & \\
Gaplek & 32,00 & 30,00 & 34,00 & 32,80 \\
Pucuk Tebu & 37,50 & 33,20 & 33,00 & 29,80 \\
Kulit Singkong & 1,50 & 3,00 & 1,80 & 1,30 \\
Molases & 8,00 & 7,40 & 8,00 & 7,30 \\
Mineral & 2,00 & 2,00 & 2,00 & 2,00 \\
Bungkil Kedelai & 19,00 & 24,4 & - & - \\
Tepung Ikan & - & - & 21,20 & 26,80 \\
\hline
\end{tabular}




\begin{tabular}{lcccc}
\hline Total & 100 & 100 & 100 & 100 \\
\hline Kandungan nutrien & & & & \\
BK & 89,89 & 91,30 & 88,95 & 89,58 \\
Dalam 100\% BK : & & & & \\
Abu & 14,16 & 14,34 & 11,45 & 18,62 \\
PK* & 13,13 & 15,20 & 13,58 & 15,20 \\
LK* & 1,15 & 1,99 & 2,76 & 6,41 \\
SK* & 14,45 & 11,99 & 12,85 & 12,63 \\
BETN** & 57,11 & 56,48 & 59,36 & 47,14 \\
TDN*** & 53,49 & 50,76 & 50,49 & 49,22 \\
\hline
\end{tabular}

Keterangan : BK = Bahan Kering; SK = Serat Kasar; LK = Lemak Kasar; PK = Protein Kasar; BETN = Bahan Ekstrak Tanpa Nitrogen; TDN = Total Digestible Nutrients.

Sumber : *) Hasil Analisis di Laboratorium Program Studi Pangan dan Gizi, Universitas Gadjah Mada, 2018.

**) BETN = $100-\% a b u-\% L K-\% P K-\% S K$

***) TDN $=$ PK tercerna $+(2,25 x$ LK tercerna $)+$ SK tercerna + BETN tercerna

\section{Prosedur penelitian}

Penelitian dilakukan selama 9 minggu dengan pemberian pakan dan minum secara adlibitum. Sanitasi kandang dilakukan setiap pagi dan sore hari untuk menjaga kebersihan kandang. Pengambilan data tingkah laku makan dan ruminasi selama 3 x 24 jam atau selama 3 hari yang dilakukan pada minggu ke-2 perlakuan. Data tingkah laku makan diperoleh dari pengamatan secara manual dengan mengamati tingkah laku ternak, yaitu eating (makan) dan rumination (ruminasi). Pengamatan dilakukan dengan mengisi formulir tingkah laku makan per 5 menit. Data yang diperoleh selanjutnya dirata- rata menjadi 24 jam.

\section{Parameter penelitian}

Parameter yang diamati dalam penelitian ini adalah waktu makan dan ruminasi. Parameter pendukung yaitu konsumsi bahan kering (BK) pakan selama 9 minggu.

Konsumsi BK (g) = Konsumsi pakan (g) $\quad$ kadar BK pakan (\%)

\section{Analisis data}

Data hasil penelitian kemudian diolah dan dianalisis menggunakan analisis varians pada taraf 5\%. Apabila terdapat perbedaan maka dilanjutkan dengan uji Wilayah Ganda Duncan. Model linear yang digunakan menurut Steel dan Torrie (1991), adalah sebagai berikut: 
Yijk $\quad=\mu+\alpha i+\beta j+(\alpha \beta) i j+e i j k$

Keterangan:

I $=$ Perlakuan perbedaan level protein $(1,2)$

$\mathrm{J}=$ Perlakuan perbedaan sumber protein $(1,2)$

$\mathrm{K}=$ Ulangan perlakuan $(1,2,3,4,5)$

Yijk = Tingkah laku makan pada petak percobaan ke-k yang memperoleh kombinasi perlakuan ij (taraf ke-i dari faktor level Protein dan taraf ke-j dari faktor sumber protein)

$\mu \quad=\quad$ Nilai tengah umum (rata-rata populasi) tingkah laku makan

$\mathrm{Ai}=$ Pengaruh aditif dari faktor level protein ke-i

$\mathrm{Bj} \quad=\quad$ Pengaruh aditif dari faktor sumber protein ke-j

$(\alpha \beta) \mathrm{ij}=$ Pengaruh interaksi faktor level protein ke-i dan faktor sumber protein ke-j

Eijk = Pengaruh galat percobaan pada petak percobaan ke-k yang memperoleh kombinasi perlakuan ij

\section{Kriteria pengujian}

Kriteria pengujian untuk analisis varians adalah sebagai berikut:

1. Apabila $\mathrm{F}$ hitung yang didapat $\geq \mathrm{F}$ tabel dengan tingkat signifikasi $5 \%$ maka pengaruh perlakuan nyata.

2. Apabila $\mathrm{F}$ hitung yang didapat $<\mathrm{F}$ tabel pada tingkat signifikasi $5 \%$, maka dikatakan pengaruh perlakuan tidak nyata.

\section{Hipotesis statistik}

Hipotesis statistik dari penelitian ini adalah :

H0: Tidak ada pengaruh pemberian level protein dan sumber protein yang berbeda terhadap tingkah laku makan dan ruminasi domba lokal muda.

H1: Terdapat pengaruh pemberian level protein dan sumber protein yang berbeda terhadap tingkah laku makan dan ruminasi domba lokal muda.

\section{HASIL DAN PEMBAHASAN}

Hasil perhitungan statistik tidak menunjukkan interaksi $(\mathrm{P}>0,05)$ antara perlakuan terhadap konsumsi bahan kering (BK), waktu makan dan waktu ruminasi. Perlakuan level dan sumber protein berbeda tidak berpengaruh $(\mathrm{P}>0,05)$ terhadap konsumsi BK, waktu makan dan waktu ruminasi. Hasil analisis ragam konsumsi BK, waktu makan dan waktu ruminasi ditampilkan pada Tabel 2. 
Tabel 2. Konsumsi bahan kering (BK), waktu makan dan waktu ruminasi

\begin{tabular}{lcccc}
\hline \multirow{2}{*}{ Parameter } & Sumber Protein & \multicolumn{2}{c}{ PK (\%) } & \multirow{2}{*}{ Rata-rata } \\
\cline { 2 - 4 } & & 13,36 & 15,20 & \\
\hline \multirow{2}{*}{$\begin{array}{l}\text { Konsumsi BK } \\
\text { (g/hari) }\end{array}$} & Bungkil Kedelai & 708,16 & 684,38 & 696,27 \\
& Tepung Ikan & 566,24 & 608,30 & 587,27 \\
\cline { 2 - 4 } & Rata-rata & 637,20 & 646,34 & \\
\hline \multirow{2}{*}{$\begin{array}{l}\text { Waktu makan } \\
\text { (menit/hari) }\end{array}$} & Bungkil Kedelai & 197,33 & 197,67 & 197,50 \\
\cline { 2 - 4 } & Tepung Ikan & 214,33 & 269,00 & 241,67 \\
\hline \multirow{2}{*}{$\begin{array}{l}\text { Waktu ruminasi } \\
\text { (menit/hari) }\end{array}$} & Rata-rata & 205,83 & 233,33 & \\
\cline { 2 - 4 } & Bungkil Kedelai & 170,00 & 147,33 & 158,67 \\
\hline
\end{tabular}

Keterangan: a, b Superskrip yang berbeda pada baris yang sama menunjukkan perbedaan yang nyata $(\mathrm{P}<0,05)$

\section{Konsumsi bahan kering (BK)}

Hasil perhitungan konsumsi BK selama penelitian menunjukkan bahwa nilai ratarata seluruh perlakuan sebesar 641,77 g/hari. Konsumsi BK yang tidak berbeda nyata $(\mathrm{P}>0,05)$ menunjukkan bahwa pakan dengan level protein berbeda memiliki pallatabilitas yang sama sehingga memacu ternak untuk terus mengkonsumsi pakan sesuai dengan kebutuhan energi dan kapasitas rumennya. Orskov (1988) menyatakan bahwa ternak akan berhenti makan ketika rumennya telah penuh terisi pakan. Hasil tersebut sejalan dengan penelitian Prima et al. (2019) bahwa domba yang diberi pakan dengan level protein berbeda (14,16 dan 18\%) menghasilkan konsumsi BK yang tidak berbeda nyata $(\mathrm{P}>0,05)$.

Pemberian pakan dengan sumber protein berbeda tidak mempengaruhi $(\mathrm{P}>0,05)$ konsumsi BK. Hal ini menunjukan bahwa penggunaan tepung ikan pada taraf yang tinggi yaitu 26,8\% tidak menurunkan palatabilitas pakan. Hasil ini berbeda dengan penelitian yang dilakukan Marjuki (2008) bahwa penggunaan tepung ikan hingga 15\% dapat menyebabkan rendahnya palatabilitas pakan karena aromanya yang tajam. Penyajian dalam bentuk pellet diindikasikan berpengaruh terhadap pallatabilitas tepung ikan karena dalam proses pembuatan pellet terjadi proses pemanasan dan penekanan (pressing) sehingga meminimalisasi aroma amis pada tepung ikan.

\section{Waktu makan}

Hasil perhitungan waktu makan menunjukkan nilai rata-rata seluruh perlakuan sebesar 219,58 menit/hari. Waktu makan tersebut lebih lama dari penelitin Prima et al. (2018) pada DET yang diberi pakan terbatas 3,5\% BB menghasilkan waktu makan 182,41 menit/hari. Galvani et al. (2010) yang dikutip oleh Sharifabadi et al. (2016) menyatakan bahwa pemberian pakan yang tidak dibatasi (ad libitum) memberikan waktu makan yang lebih lama. Level protein pakan yang berbeda (13,36 dan 15,20\%) tidak berpengaruh $(\mathrm{P}>0,05)$ terhadap waktu makan. Hasil serupa juga diperoleh pada penelitian Pembayun et al. (2013) dengan menggunakan kambing Kacang, pemberian pakan dengan level protein berbeda (9,20\%, 11,67\% dan 18,33\%) menghasilkan waktu makan yang 
sama. Hal tersebut dapat diduga disebabkan karena kandungan serat kasar (SK) yang hampir sama pada PK 13,36 dan 15,20\% (Tabel 1). Adiwinarti et al. (2019) menyatakan bahwa semakin banyak asupan serat kasar maka akan semakin lama waktu mengunyah.

Sumber protein yang berbeda tidak berpengaruh $(\mathrm{P}>0,05)$ terhadap waktu makan. Ukuran partikel yang kecil dari bungkil kedelai dan tepung ikan, menyebabkan luas permukaan yang sama sehingga diduga menghasilkan tingkat kunyahan yang sama. Disamping itu, penyajian pakan dalam bentuk pellet diduga juga memberikan tingkat kunyahan yang sama. Lee et al. (2010) menyatakan bahwa bentuk fisik pakan dan karakteristik pakan mempengaruhi waktu makan.

\section{Waktu ruminasi}

Hasil perhitungan waktu ruminasi menunjukkan nilai rata-rata seluruh perlakuan sebesar 163 menit/hari. Waktu ruminasi yang tidak berbeda nyata $(\mathrm{P}>0,05)$ mengindikasikan bahwa laju pakan dalam rumen sama. Cardoso et al. (2017) menyatakan bahwa waktu ruminasi dapat digunakan untuk menentukan laju pakan di dalam saluran pencernaan. Perlakuan level protein 13,36 dan 15,20\% diduga tidak mempengaruhi waktu ruminasi karena konsumsi BK yang dihasilkan tidak berbeda nyata $(\mathrm{P}>0,05)$. Konsumsi BK berpengaruh terhadap banyaknya produk fermentasi dalam rumen. Bata \& Sodiq (2014) menyatakan bahwa produk fermentasi dalam rumen dipengaruhi oleh tingkat konsumsi BK pakan. Jumlah produk fermentasi yang sama menyebabkan bolus yang dikeluarkan untuk remastikasi sama sehingga waktu ruminasi sama.

Perlakuan sumber protein berbeda tidak mempengaruhi $(\mathrm{P}>0,05)$ waktu ruminasi. Tepung ikan sebagai sumber protein bypass tidak memacu ternak melakukan proses ruminasi lebih cepat. Dartosukarno et al. (2012) juga menyatakan bahwa waktu ruminasi lebih dipengaruhi oleh banyaknya total pakan yang diruminasi daripada kualitas atau komposisi pakan. Tinggi rendahnya degradasi protein diduga tidak berpengaruh terhadap degradasi partikel pakan sedangkan ruminasi akan berhenti ketika partikel pakan dapat lolos dari rongga rumen sehingga tidak terjadi proses regurgitasi dan remastikasi. Ferreira et al. (2011) menyatakan bahwa ukuran partikel minimum yang merangsang kegiatan ruminasi atau remastikasi yaitu $1,18 \mathrm{~mm}$.

\section{Pola aktivitas makan dan ruminasi}

Pola aktivitas makan dan ruminasi ditampilkan pada Ilustrasi 1 dan 2. Pola aktivitas makan dan ruminasi berbanding terbalik dimana saat aktivitas makan tinggi maka aktivitas ruminasi rendah dan sebaliknya. Meskipun setiap perlakuan memiliki waktu makan yang berbeda namun menghasilkan fluktuatif yang hampir sama. Pada grafik, T4 cenderung memiliki waktu makan yang lebih tinggi dari T1, T2 dan T3 namun secara statistik tidak berbeda nyata $(\mathrm{P}>0,05)$. Hal tersebut diduga karena kandungan tepung ikan pada pakan yang tinggi sehingga waktu makan cenderung lebih lama karena tepung ikan memiliki rasa asin sehingga ternak lebih sering mengeluarkan saliva untuk menetralisir rasa asin. 


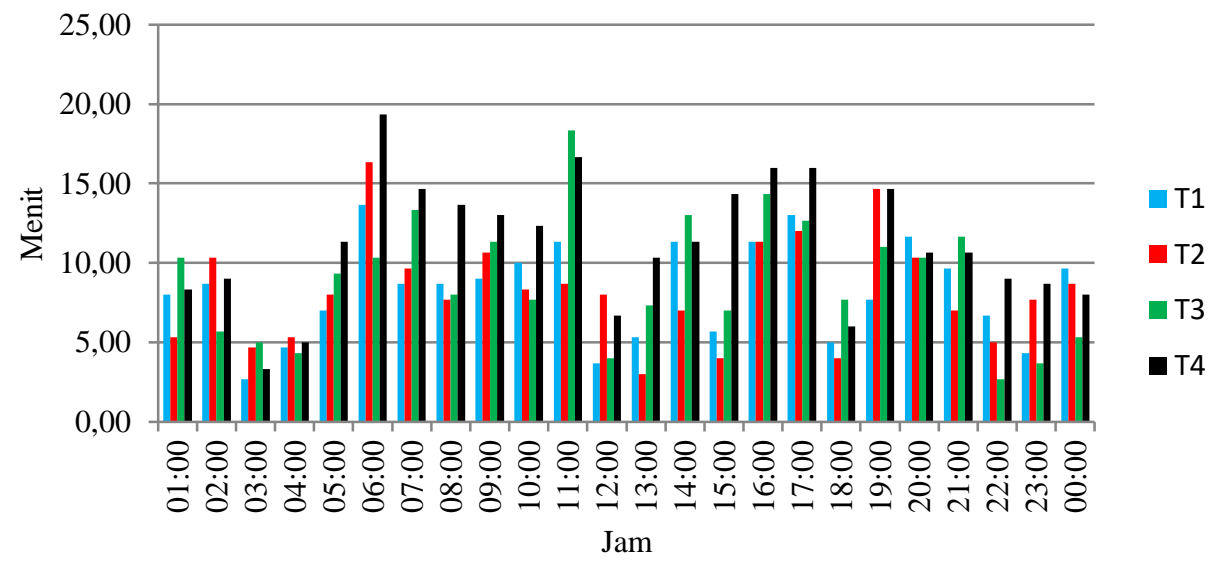

Gambar 1.Pola aktivitas makan domba lokal muda yang diberi pakan dengan level dan sumber protein berbeda

Pola aktivitas ruminasi menunjukkan bahwa aktivitas ruminasi meningkat pada jam 0:00-6:00. Hal tersebut diduga pada jam 19:00-0:00 ternak mengkonsumsi banyak pakan sehingga menghasilkan produk fermentasi yang tinggi. Peningkatan proses ruminasi tersebut juga digunakan ternak untuk proses homeostatis karena diduga pada jam 0:006:00 suhu lingkungan sangat rendah.

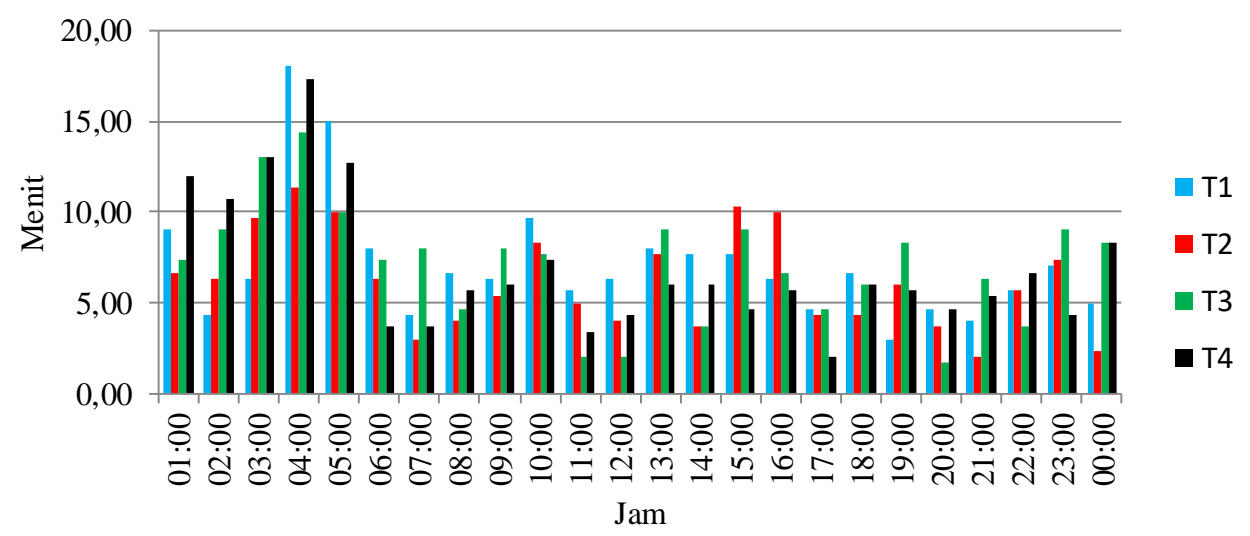

Gambar 2.Pola aktivitas ruminasi domba lokal muda yang diberi pakan dengan level dan sumber protein berbeda

\section{KESIMPULAN}

Berdasarkan hasil penelitian dapat disimpulkan bahwa pemberian pakan dengan level dan sumber protein berbeda tidak mempengaruhi tingkah laku makan domba lokal muda. 


\section{DAFTAR PUSTAKA}

Adiwinarti R, Lestari CMS, Purnomoadi A. 2019. Feeding behaviour and drinking activities of Kacang goat fed high and low fiber diets. IOP Conf Ser Earth Environ Sci. 247:1-5.

Bata M, Sodiq A. 2014. Tingkah laku makan sapi Peranakan Ongole yang diberi pakan berbasis jerami padi amoniasi dengan metode pemberian yang berbeda. J Agripet. 1:1724.

Dartosukarno S, Iskandar S, Purnomoadi A. 2012. Effect of level of concentrate feeding level on efficiency of eating behaviour on ongole crossbred cattle. J Indones Trop Anim Agric. 37:22-26.

Ferreira EM, Pires AV, Susin I, Mendes CQ, Gentil RS, Araujo RC, Loerch SC. 2011. Growth, feed intake, carcass characteristics, and eating behavior of feedlot lambs fed high-concentrate diets containing soybean hulls1. J Anim Sci. 89:4120-4126.

Galvani DB, Pires CC, Wommer TP, Oliveira F, Santos MF. 2010. Chewing patterns and digestion in sheep submitted to feed restriction. J Anim Physiol Anim Nutr. 94:e366e373.

Goetsch AI, Gibson TA, Askar AR, Puchala R. 2010. Feeding behavior of goat. J Anim Sci. 88:361-373.

Ilham F. 2017. Pertumbuhan pra dan pascasapih domba lokal pada padang penggembalaan di musim yang berbeda. Yogyakarta (Indonesia): Zahir Publishing.

Lee S, Kim Y, Oh Y, Kwak W. 2010. Effects of feeding methods of total mixed ration on behavior patterns of growing Hanwoo steers. Asian-Aust J Anim Sci. 23:1469-1475.

Marjuki. 2008. Penggunaan tepung ikan dalam pakan konsentrat dan pengaruhnya terhadap pertambahan bobot badan kambing betina. J Ternak Tropika. 9:90-100.

Orskov ER. 1988. The feeding of ruminant principles and practice. Marlow (USA): Chalombe Publisher.

Pembayun IH, Purnomoadi A, Dartosukarno S. 2013. Tingkah laku makan kambing kacang yang duberikan pakan dengan level protein-energi berbeda. J Anim Agric. 2:31-36.

Prima A, Purbowati E, Rianto E, Purnomoadi A .2019. The effect of dietary protein levels on body weight gain, carcass production, nitrogen emission, and efficiency of productions related to emissions in thin-tailed lambs. Vet World. 12:72-78.

Prima A, Luthfi N, Rianto E, Purnomoadi A. 2016. Body weight gain and feed efficiency of young thin - tailed sheep raised under intensive feeding at different level of protein. International Conference on Tropical Animal Science and Production. Bangkok. p. 283286.

Prima A, Rianto E, Purbowati E, Purnomoadi A. 2018. Indirect evaluation of digestive tract function on male lambs and ram based on feed digestibility and eating behavior. JITAA. 43:124-130.

Puastuti W, Mathius IW. 2008. Respon domba yang mendapat ransum dengan sumber protein berbeda: tinjauan pada komposisi kimia tubuh dan pertumbuhan wool. Prosiding Seminar Nasional Teknologi Peternakan dan Veteriner. Bogor (Indonesia): Pusat Penelitian dan Pengembangan Peternakan.

Purnomoadi A. 2018. Early fattening lamb could mitigate methane productiont-an example of climate smart livestock farming system in Indonesia. IOP Conf Ser Earth Environ Sci. 119:1-9. 
Riyanto A, Adiwinarti R, Dartosukarno S, Purnomoadi A. 2015. Effisiensi untuk waktu makan dun ruminasi kambing kacang yang diberi pakan dengan sumber protein yang berbeda. Dalam: Solihati N, et al., penyunting. Prosiding Seminar Nasional Peternakan Berkelanjutan 7. Sumedang (Indonesia): Universitas Padjajaran. hlm. 340-344.

Sabilla AM, Rianto E, Purnomoadi A. 2018. pengaruh pemberian pakan dengan kadar protein yang berbeda terhadap waktu makan dan ruminasi pada kambing kacang muda. Dalam: Sarjana TA., Karno, Sugiharto, penyunting. Prosiding Seminar Nasional Kebangkitan Peternakan III. Semarang (Indonesia): Universitas Diponegoro. hlm. 559-563.

Sharifabadi RH, Naserian AA, Valizadeh R, Nassiry MR, Bottje WG, Redden R R.2016. Growth performance, feed digestibility, body composition, and feeding behavior of high- and low-residual feed intake fat-tailed lambs under moderate feed restriction1. J Anim Sci. 94:3382-3388.

Uhi HT. 2006. Perbandingan suplemen katalitik dengan bungkil kedelai terhadap penampilan domba. JITT. 6:1-6. 